12.00.0o Legal sciences

12.0о.оо Юридические науки

UDC 349.442

\title{
On the Term of 'Working Papers' in Russian law of Civil Engineering
}

\author{
Igor N. Polovtsev
}

Saint-Petersburg State University, Russia

7/9 Universitetskaya emb., Saint-Petersburg, 199034

Deputy Head of Building \& Reconstruction Division

E-mail: i.polovtsev@spbu.ru

Abstract. The article examines the term of 'working papers' and their role in the construction process. The term of 'working papers' is analysed as applied in laws and other legal acts. The author thinks it necessary for the legislators to give a precise definition of the term.

Keywords: designing; working papers; civil engineering; construction work; state order; city-planning legislation; Russian building law.

On February 16, 2008, the Government of the Russian Federation approved the Regulations on the structure of the sections of design documentation and requirements to their contents [1]. Before that, the Russian Federation stipulated three stages of designing: Feasibility Report or Predesign Studies, Design and Contractor Design. Since 2008, designing has been divided in two stages: Design Documentation and Working Papers.

Development of requirements to design documentation approved by the Government of the Russian Federation contributed to regulation of architectural and building activity. Before that, the activity was regulated by departmental acts issued by various ministries. Such practice led to contradictions between documents and uncertainty of the legal status of these documents.

The Regulation involved stipulates the exact structure of the design documentation developed by design organisations. As far as the working papers are concerned, the Regulation only stipulates that it has been developed to implement architectural, technical and technological decisions stipulated by design documentation in the course of construction. The working papers can consist of text documents, workshop drawings, data sheets of the equipment and articles.

The City-Planning Code of the Russian Federation stipulates obligatory approval of design documentation by the builder or the technical customer of the design documentation. In the cases identified by the City-Planning Code, design documentation shall preliminarily receive a positive expert judgement. The expert appraisal procedure has been stipulated by the Government of the Russian Federation [2]. The projects financed from the federal budget shall be additionally checked for reliability of the construction budget [3].

Proceeding from Article 743 of the Civil Code of the Russian Federation, the contractor shall build according to the engineering specifications [4]. The engineering specifications stipulate the scope and the content of work. The budget stipulates the costs of work. The structure and the content of the engineering specifications shall be stipulated by the building contract. The federal legislation on placement of state and municipal orders stipulates the necessity to publish construction documents/engineering specifications [5] [6].

Calculation of the exact construction estimate is only possible if the design documentation gives full description of all units, and the data sheet specifies all the materials used. Any change in either the above or the technology can affect the estimated cost of the project [7].

By the moment of conclusion of the building contract, the scope of civil and erection works and their cost shall be determined for good and all. Consequently, all design decisions necessary for construction shall be made at the stage of development of the design documentation [8]. That was the conclusion made in the letter of the Ministry of Regional Development dated August 8, 2008 [9]. The letter stipulates that the volume of the design documentation shall approximately correspond to that of the stage previously referred to as the Contractor Design. It also stipulates 
that the customer shall prepare the design documentation in the volume sufficient for state expert appraisal and building.

However, it was as soon as on June 22, 2009 that the Ministry of Regional Development recognised the letter dated August 8, 2008 as void. And on the next day, it disavowed its legal position. The Ministry stated that the volume of studies at the stage of Design Documentation cannot correspond to the volume of the earlier developed stage of Contractor Design as the stage of Contractor Design used to stipulate complete development of working papers and development of the part subject to approval (Design) in a short form.

We do not believe the argument advanced by the Ministry of Regional Development to be lawful. There was no term of 'working papers' before 2008. It could not characterise the term of 'contractor design'.

At present, the volume and the structure of the working papers have not been regulated by normative legal documents. According to the position repeatedly stated by the Ministry of Regional Development, the volume, the structure and the contents of the working papers shall be stipulated by the customer/builder depending on the degree of detailed elaboration of the decisions stipulated by the design documentation. The volume and the structure of the documentation shall be specified in the design task [10].

In 2010, the Ministry of Regional Development approved Construction Engineering Projects, a handbook of basic prices for design work in civil engineering [11]. According to the handbook, the designing costs of the stages of Design Documentation and Working Papers are at a ratio of two to three, respectively. The same handbook stipulates the list of sections of the working papers. The list fully coincides with the sections of the design documentation.

The Civil Code allows 10\% change of the price of the building contract. Hence, the applied materials, scope of work and technologies can only be changed within 10\%. Amendment of the papers automatically entails change of the estimated cost. It is not allowed in case of construction within the framework of state and municipal purchases (except for the cases of restoration work).

The current city-planning legislation allows amendment of design documentation. Repeated expert appraisal is only required in the cases of change of technical decisions affecting constructive reliability and safety of the capital construction project.

As a result, the design organisation has a right to complete the design documentation by adding the necessary units or technological decisions; for example, within the framework of the guarantee obligations stipulated by Article 761 of the Civil Code of the Russian Federation.

The Ministry of Regional Development has approved the list of works to be done in engineering survey, preparation of design documentation, building, reconstruction, general overhaul of capital construction projects that affect safety of capital construction projects [12]. Having analysed this document, the Federal Antimonopoly Service concluded that development of the working papers does not affect safety of capital construction projects. Consequently, the contractor does not have to have a Permit-to-Work issued by a self-regulated organisation. That means that the working papers cannot anyhow affect/adjust/change the elements stipulating safety of buildings and structures. Hence, development of working papers needs persons of lower qualification than development of design documentation. The reason is that working papers do not develop structures or units affecting the elements stipulating safety of capital construction projects.

Actually, development of working papers is adjustment of the design documentation approved by the builder. Under such conditions, such work cannot be $150 \%$ initial cost of development of design documentation (if the designing costs of the stages of Design Documentation and Working Papers are at a ratio of two to three, respectively, the cost of the stage of Working Papers is 150\% cost of the stage of Design Documentation).

According to the City-Planning Code, it is design documentation that regulates the entire building process as the main document. A building person shall build, renovate, overhaul a capital construction project according to the design documentation. The construction process is controlled to check compliance of the work done with the design documentation. A Permit to Commission a Project is a document certifying full compliance of building and renovation of the capital construction project with the design documentation.

So, Working Papers are not a ground for construction. Working papers are not a document intended to control construction. 
Complex consideration of the term of 'working papers' allows concluding that the present legal position held by the Ministry of Regional Development as far as the status of working papers is concerned is not right. It reduces responsibility of design organisations for development of design documentation by allowing them to leave development of important and complex units until later, viz. up to the stage of development of working papers. It can lead to wrong calculation of the estimated cost of a construction project. It can lead to violation of the antimonopoly law by state customers. In case of construction financed from budgets of all levels, it changes the cost of capital investments and leads to additional unpredicted expenditure of the budget. The result is delay in implementation of investment projects.

In our opinion, it is necessary to have normative legal regulation of the structure and the contents of working papers. It is necessary to give a precise definition of the place and the role of working papers in construction. It is also essential to study the issue of the price of working papers.

\section{References:}

1. Regulation on the structure of the sections of design documentation and requirements to their contents: approved by the statement of the Government of the Russian Federation dated February 16, 2008 No. 87 // Collection of legislation of the Russian Federation. - 2008. - No.8.

2. On the procedure of organisation and holding of state expert appraisal of design documentation and results of engineering surveys. Statement of the Government of the Russian Federation dated March 5, 2007 No.145 // Collection of legislation of the Russian Federation. 2007. - No.11, Article 1336.

3. On the procedure of checking whether the estimated cost of capital construction projects to be built with attraction of the federal budget funds was determined in a reliable way. Statement of the Government of the Russian Federation dated May 18, 2009 No.427 // Collection of legislation of the Russian Federation. - 2009. - No.21, Article 2576.

4. Civil Code of the Russian Federation. Part II (revision dated 30.11.2011). Federal Law of January 26, 1996 No.14-FZ. // Collection of legislation of the Russian Federation. - 1996. - No.5, Article 410.

5. Letter by the Federal Antimonopoly Service dated July 23, 2010 No. IA/23610 [Electronic resource]. The document was not published. Access from the legal reference system of ConsultantPlus (access of 01.02.2012).

6. Polovtsev I.N. On the documentation volume necessary to hold placement of orders in the field of building//Economics, sociology and law. 2011. № 6. p.70-72.

7. Lushchikova T.N. Impact of construction organisation project on the estimated cost of the construction // Research-production-technology-ecology: Collected papers. vol.5. MachineBuilding Automation Faculty, Civil Engineering Faculty. Kirov: VyatGU Publishing House. 2006.

8. Maslyayev A.V. Blue-print stages of earthquake-resistant liable buildings // Bulletin of Volgograd State University of Architecture and Civil Engineering. Series: Civil Engineering and architecture. 2010.

9. Letter by the Ministry of Regional Development dated 08.08.2008 No.19512-SM/o8 // Pricing and cost estimating in civil engineering, 2008, No.11.

10. Kuznetsov Y.V. Recent requirements to expert appraisal and structure of design documentation and working papers of Joint Stock Company «Transneft». Research and technologies of pipeline transportation of oil and oil products. 2011, No. 3 .

11. On approval of handbooks of basic prices for design work in civil engineering. Order by the Russian Federation Ministry of Regional Development dated May 28, 2010 No. 260 // Bulletin of statutory acts by federal executive authorities, 2010, No. 45.

12. On approval of the list of works to be done in engineering survey, preparation of design documentation, building, reconstruction, general overhaul of capital construction projects that affect safety of capital construction projects. Order by the Russian Federation Ministry of Regional Development dated December 30, 2009 No.624 (revision dated 14.11.2011) // Rossiyskaya gazeta 2010, No.88. April 24. 
УДК 349.442

\title{
О понятии «рабочая документация» в российском строительном праве
}

\author{
Игорь Николаевич Половцев
}

Санкт-Петербургский государственный университет, Россия Университетская наб. д.7/9, Санкт-Петербург, 199034

Заместитель начальника управления капитального строительства и реконструкции E-mail: i.polovtsev@spbu.ru

Abstract. В статье рассматривается понятие «рабочая документация» и ее место в процессе строительства. Проводится анализ применения термина «рабочая документация» в законах и в других правовых актах. Автор приходит к выводу о необходимости законодательно определить это понятие.

Keywords: проектирование; рабочая документация; строительство; строительный подряд; государственный заказ; градостроительное законодательство; российское строительное право. 